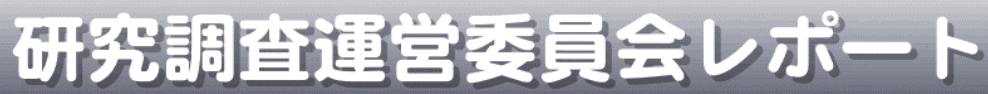

\section{調査専門委員会および協同研究委員会 委員の公募}

\begin{tabular}{|c|c|c|c|}
\hline \multicolumn{2}{|c|}{$\begin{array}{l}\text { 委員会名 } \\
\text { 【技術委員会】 }\end{array}$} & $\begin{array}{c}\text { 上下水道施設における環境負荷低減技術 } \\
\text { 調査専門委員会 } \\
\text { 【公共施設技術委員会】 }\end{array}$ & $\begin{array}{c}\text { 委員会での調査・検討項目の概要, } \\
\text { 委員長のメッセーシ等 }\end{array}$ \\
\hline \multicolumn{2}{|c|}{ 設置期間 } & 平成 21 年 12 月 平成 23 年 11 月 & \multirow{8}{*}{ 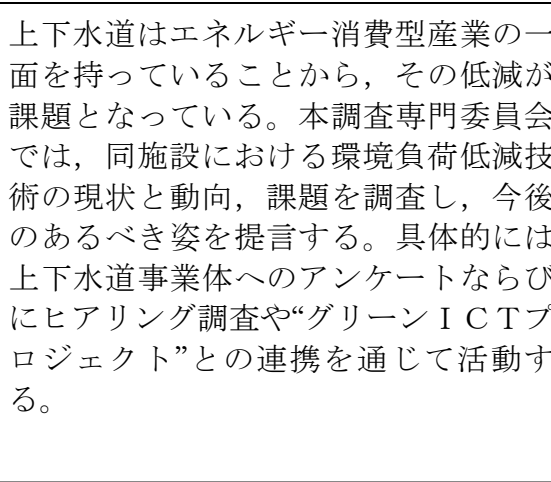 } \\
\hline \multirow{2}{*}{\multicolumn{2}{|c|}{$\begin{array}{l}\text { 委員長名 }(\text { 所属 }) \\
\text { 委員会開催頻度 }\end{array}$}} & 新 誠一 (電気通信大学 $)$ & \\
\hline & & 6 回/年 & \\
\hline \multirow{4}{*}{ 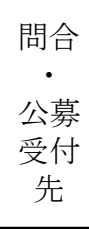 } & 氏名 (所属) & 田所 秀之（日立製作所情報制御システム社） & \\
\hline & 電話 & $0294-53-2944$ & \\
\hline & FAX & $0294-53-7780$ & \\
\hline & $\begin{array}{l}\text { E-mail } \\
\text { アドレス }\end{array}$ & hideyuki.tadokoro.dw(at)hitachi.com & \\
\hline \multicolumn{2}{|c|}{$\begin{array}{l}\text { 応募いただきたい方の } \\
\text { 専門分野, 経験など }\end{array}$} & $\begin{array}{l}\text { 電気工学, 機械工学, システム工学, 上下水道 } \\
\text { 工学 }\end{array}$ & \\
\hline \multicolumn{2}{|c|}{ 応募締切 } & 平成 22 年 8 月 31 日 & \\
\hline \multicolumn{3}{|c|}{ 協同研究委員会の場合の委員の負担 } & 0 円 $/$ 年 \\
\hline
\end{tabular}

\section{最近発行の電気学会技術報告}

（産業応用部門関係委員会発行分の技術報告書）

ご購入希望の方は, 電気学会ホームページ「電気学会 電子図書館」(http://www.bookpark.ne.jp/ieej/)をご参照ください。

なお, 電子図書館で販売している技術報告・書籍は, 電気学会の事務局で直接販売していませんのでご了承ください。

\begin{tabular}{|c|c|c|c|c|c|}
\hline 号数 & 技術報告タイトル名 & 執筆委員会名 & 発行日 & 頁 & 価格 \\
\hline 1169 & 新世代の電気・磁気アクチュエータ & $\begin{array}{l}\text { 新世代の電気・磁気アクチュエータ調査 } \\
\text { 専門委員会 }\end{array}$ & 2009年9月 & 52 & 3,024 \\
\hline 1168 & 電磁界解析による回転機の設計・性能評価技術 & $\begin{array}{l}\text { 電磁界解析による回転機の設計・性能評 } \\
\text { 価技術調査専門委員会 }\end{array}$ & 2009年8月 & 70 & 3,528 \\
\hline 1165 & $\begin{array}{l}\text { 産業部分野における省エネルギー技術の適用動 } \\
\text { 向と課題 }\end{array}$ & $\begin{array}{l}\text { 省エネ法改正に伴う生産現場に: } \\
\text { エネ技術の適用動向調查専門委 }\end{array}$ & : 7 月 & 68 & 3,402 \\
\hline 1161 & $\begin{array}{l}\text { 移動体用エネルギーストレージ技術の現状と展 } \\
\text { 望 }\end{array}$ & $\begin{array}{l}\text { 移動体エネルギーストレージ技術調査専 } \\
\text { 門委員会 }\end{array}$ & 2009年7月 & 70 & 3,528 \\
\hline 1156 & $\begin{array}{l}\text { 磁気支持応用における電気・機械システム融合 } \\
\text { 化技術の動向 }\end{array}$ & $\begin{array}{l}\text { 磁気支持応用における電気・機械システ } \\
\text { ム融合化技術調査専門委員会 }\end{array}$ & 6月 & 52 & 3,024 \\
\hline 1155 & $\begin{array}{l}\text { 家庭等におけるおブロードバンド時代の情報通信 } \\
\text { システムさひ機器のエネルギー技術動向 }\end{array}$ & $\begin{array}{l}\text { こおけるブロードバンド時代の情 } \\
\text { システムおよび機器のエネル゙ギー } \\
\text { 句調查専門委員会 }\end{array}$ & 200 & 59 & 3,276 \\
\hline 1154 & $\begin{array}{l}\text { 産業用リニア電磁駆動システムの要素技術とそ } \\
\text { の動向 }\end{array}$ & \begin{tabular}{|l} 
産業用リニア電磁駆動システム \\
術調査専門委員会
\end{tabular} & 5月 & 56 & 3,150 \\
\hline 1151 & $\begin{array}{l}\text { ソフトコンピューティングの新展開とその産業 } \\
\text { 応用 }\end{array}$ & $\begin{array}{l}\text { ソフトコンピューティングの新展開とそ } \\
\text { の産業応用調査専門委員会 } \\
\end{array}$ & E4月 & 146 & 5,544 \\
\hline 1146 & IT化監視制御システムの構成技術 & IT化監視制御技術協同研究委員会 & 2009年2月 & 44 & 2,772 \\
\hline 1145 & PMモータの最新技術と適用動向 & PMモータの産業応用調査専門委員会 & 2009年1月 & 60 & 3,276 \\
\hline 1143 & 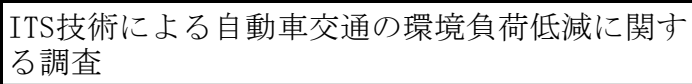 & $\begin{array}{l}\text { ITS技術による自動車交通の環境負荷低 } \\
\text { に関する調査専門委員会 }\end{array}$ & 2009年1月 & 60 & 3,276 \\
\hline
\end{tabular}

